Claiming publicness for work

Helena Lopes*

WP n. $02012 / 04$

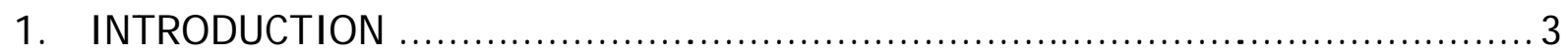

2. RECOGNI ZING THE POLITICAL CHARACTER OF WORK $\ldots \ldots \ldots \ldots \ldots \ldots \ldots \ldots \ldots \ldots$

3. THE DEFINING FEATURES OF THE PUBLIC SPHERE AND THE EXTENT IN WHICH THEY APPLY TO THE WORK SPHERE 10

4. NORMATIVE IMPLICATIONS OF THE RECOGNITION OF THE PUBLIC CHARACTER OF WORK 13

5. CONCLUDING REMARKS 19

References 21

*DINÂMIA’CET - IUL and ISCTE - IUL. 



\title{
Claiming publicness for work
}

\begin{abstract}
:
Mainstream economists and social philosophers like Arendt and Habermas conceive work as an instrumental activity. This instrumental conception of work results from the way in which work is regarded: as a relation between men and nature rather than a relation between men. Work is then relegated to the private, non-political domain. Conversely, we argue that work entails a co-operative and intersubjective character, which endows work, as experienced by workers, with an inescapable political and public dimension. These analytical claims lead us to question the strict distinction between the public and the private in contemporary democratic societies and adopt a normative perspective. Major normative implications are that work-related issues should be transformed from private practices to public matters and that participatory workplaces should be promoted by public regulation.
\end{abstract}

Keywords: concept of work, public sphere, Hannah Arendt, democracy at work

JEL: J01, J50, J81

The struggle over what gets included in the public agenda is itself a struggle for justice and freedom (Seyla Benhabib, 1992:79). 



\section{INTRODUCTION}

In a time when work goes through an unprecedented process of depreciation and the quality of work life deteriorates almost everywhere, work issues are a very much secundarized subject among economists, including heterodox economists. Normative claims about how work should be organized have largely been handed over to managerial sciences, a process that contributes to legitimatizing the long-standing liberal contention that work governance is an exclusively private matter. It is as if economists had renounced to study the world of work and promote the changes that would bring about desired social and economic outcomes.

This state of affairs no doubt stems from historical and ideological factors but may also be explained by theoretical reasons, related to the way in which work is conceptualized by most economists and social philosophers. For mainstream economists, work is an instrumental activity in which socially dis-embedded individuals engage solely to have access to consumption. Leading philosophers, like Hannah Arendt and Jurgen Habermas, emphasize also the instrumental nature of work, supposed to put men in relation with nature and in strategic relations with others. Since the public sphere is defined by free non-strategic interaction among equal individuals, work is relegated to the private, non-political domain. In our view, this instrumental, depoliticized, conception of work and its consequent exclusion from the public sphere has contributed to underrate work and is progressively ruling it out of the "elevated" academic matters.

The aim of the present paper is to argue that workplaces are political (in the arendtian sense) arenas and that work has an irreducible political and public dimension. Although this approach runs against the dominant contention, we are not alone in our endeavour. Authors such as Pateman (1970), Honneth (1982), Ferreras (2007) or Dejours (2009) have also been advocating the recognition of the public character of work. We develop our argument in three steps, beginning with an analytical stance and ending with a normative one.

Firstly it is pointed out that the instrumental conception regards work as relating men with nature but not with each other. In economics, for instance, the marginalist (instrumental) conception of work accompanies the eviction of the relations between men from the domain of economic analysis. Yet, work activities are almost always undertaken within a network of social interactions, many of which, pace Habermas, are not of a strategic nature. Institutional economics and sociological approaches assume since long that work is a collective, co-operative venture enduringly permeated by normative concerns and justice aspirations. Now, a major constitutive feature of the public sphere is precisely that it deals with collective activities marked by key normative challenges.

The second part of the paper examines the extent in which the conditions for a public sphere, as conceived by Habermas and Arendt, are met in private business workplaces, and whether these

DINÂMIA'CET - IUL, Centro de Estudos sobre a Mudança Socioeconómica e o Território 
conditions are effectively required for an arena to be considered public. Our conception of work leads us to question the private/public distinction in contemporary societies and discuss equality as a criterion for a public sphere.

The third part assumes that the "publicness" of work is not solely a theoretical but also a political issue. Some of the normative counterparts of the recognition of the public character of work are hence explored. Firstly, making an issue public means making it accessible to debate and public scrutiny. We point out that the opposite is presently observed concerning work: the demands of competitiveness are rendering the changes being undergone in the world of work almost invisible and unquestioned. For instance, the current intensification of work and declining work autonomy (Green, 2006) are hardly denounced. Like pay and health, such questions should be transformed from private business practices to matters of public concern and issues of justice. Secondly, public regulation and policies aimed at promoting the democratization of work become required and legitimate. Indeed, if it is recognized that workplaces have a public dimension, they should be subject to the same principle that applies to the public sphere, namely the maximum possible participation of all those involved.

Section two briefly presents the conceptions of work relevant for our purposes and argues, contra Arendt (1958), that work is a political activity. Section three builds on Arendt (1958) and Habermas (1989) to examine the extent in which workplaces can be regarded as embodying a public dimension. Section four develops the normative corollaries generated by the acknowledgement of work as public and section five concludes.

\section{RECOGNIZING THE POLITICAL CHARACTER OF WORK}

\section{Work as an instrumental and solitary activity}

Mainstream economists portray work as a production factor for firms and a source of disutility for workers, an unpleasant activity which people would avoid if they could. Workers are assumed to entertain an instrumental relation with work, which is merely a means to the "real" end, i.e. consumption $^{1}$. Non-incidentally, the authors who formalized this vision of work, the early marginalists, are also those who restricted the object of economics to the study of the relations between men and nature. For them, economics would exclusively deal with the "lower elements of human nature”, that is, self-interest and the search for material wealth.

Although mainstream economics has meanwhile largely broadened its scope by introducing social preferences into utility functions, the rational economic agent still acts instrumentally toward

\footnotetext{
${ }^{1}$ Institutional economists, by contrast, have always challenged this view, highlighting the fact that work is not simply a means to consumption; it could also be a privileged means for human flourishing (Spencer, 2009; Lopes, 2011).
} 
others. His social relations are just means by which, or constraints within which, he pursues the goal of utility-maximization and the individualistic ground of rational choice theory is left untouched. The worker as a producer embedded in a social productive context had been replaced in economic theory by the worker as a consumer.

In turn, contemporary social philosophy is marked by the underating of work, which contributed to dismantle the emancipatory status of the $19^{\text {th }}$-century concept of work (Honneth, $198^{2}$ and Ferreras, 2007). The theoretical milestones along this path are Arendt and Habermas, for whom, like in mainstream economics, work involves the relations between men and nature.

For Habermas, work broadly refers to the way individuals control and manipulate their environment. Work is regulated by the technical rules that govern the interactions between men and nature; it is hence typically and necessarily an externally regulated and controlled type of behaviour. Though he recognizes that work activity is immersed in social interactions, he sharply distinguishes work and interaction (Habermas, 1968). Work as an activity and the relations in which individuals enter while at work belong to the domain of instrumental/strategic action. Work is an instrumental action which consists in finding the best technical means in the pursuit of predefined goals. Relations established at work, in turn, are regarded as strategic action - consisting in choosing the strategy adequate to one's goals while knowing that others are also pursuing their own goals. In workplaces then, individuals are assumed to view their co-workers as if they were objects or organizational resources, likely to be manipulated if necessary. Workplaces, like all other economic affairs, are governed by the diktats of instrumental reason.

In contrast with work, interaction is oriented by the mutual search for understanding rather than directed to a goal and is associated to communicative action. The latter is governed by social norms shared by the interacting individuals and characterized by the absence of coercive force. While in work individuals primarily relate with nature, communicative action is a fundamentally dialogic activity, marked by interaction and identity formation. For Habermas, communicative action is the cement of social order; a society would not hold together with instrumental and strategic action alone. But for him communicative action is only possible among free and equal individuals, which means out of work, in the public sphere.

Habermas' framework meets Arendt's theorization of the human condition as constituted by three activities: labour, work and (political) action. Labour and work ${ }^{2}$ are instrumental activities in the sense that they are directed to a goal other than themselves. Labour is forced upon human beings by their biological condition; so, men as labourers are bound to necessity and deprived of liberty. Arendt condemns modern societies for them having become societies of labourers/consumers: modern men and women compel themselves to the never-ending cycle of production and reproduction, endlessly

\footnotetext{
${ }^{2}$ For the sake of simplicity, we only consider here Arendt's concept of labour because her concept of work does not differ significantly from that of labour concerning what is of specific interest to us.
} 
producing in order to consume and consuming in order to produce. In contrast, (political) action does not pursue any end; the end lies in the activity itself. Action lies outside the category of means and ends because the means to achieve the ends - that is, the virtues - are already the end; indeed, for Arendt and her Aristotelian inspiration there is nothing higher to obtain than the exercise of virtue.

With regard to social interactions at work, Arendt's position is even more radical than Habermas':

"Labouring is an activity in which man is neither together with the world nor with other people, but alone with his body, facing the naked necessity to keep himself alive. [...] It is indeed in the nature of labouring to bring men together in the form of a labour gang where any number of individuals 'labour together as if they were one'. [...] But this 'collective nature of labour', far from establishing a recognizable, identifiable, reality for each member of the labour gang, requires on the contrary the actual loss of all awareness of individuality and identity. [...] The sociability arising out of [labour] rests not on equality but on sameness" (Arendt, 1958, pp. 212-213).

That is, in the realm of labour, human beings are all alike because they are mere living organisms, stuck to materiality; they thus are interchangeable instead of unique and distinct individuals. In contrast, Arendt's notion of action, like Habermas' communicative action, is defined by equality and distinction because action goes on directly between men without the intermediary of things. It is through action and speech, that is, in the public sphere and not in workplaces, that individuals reveal their individuality and display their virtue and character; the principal trait of action is "the disclosure of who.”

\section{Beyond instrumentality}

So, Arendt and Habermas, like mainstream economics, make two distinct but related contentions: i) work is an instrumental activity and ii) workplaces are inhabited by indistinct, un-individuated, individuals who only relate instrumentally to each other. Regarding the first assertion, it is important to remind that prominent thinkers, among which Marx, believed that work is valuable in itself, rather than a mere instrument to something else, because through work human beings could exercise their creative powers and hence achieve self-realization (Spencer, 2009). For Marx, work is not an alienating activity in itself; rather, it has been so because within capitalism the organization of work is decided and controlled by managers, and this puts subjectivity in danger. But the focus of the present paper is to discuss the second assertion: do individuals only nurture instrumental relations in workplaces? 
More than three decades ago, Honneth (1982) denounced the narrowing of the concept of work to action directed exclusively at the practical domination of nature. According to him, work must not be conceived as separated from subjectivity. Sociology of work actually and forcefully shows that work does not solely consist in a series of tasks carried out in an objective world; work is also made of how work is subjectively experienced, perceived and interpreted. As work is seldom undertaken in isolation, this implies that workplaces must be conceived as intersubjective interaction contexts. In addition, since the concepts of work are always informed by their historical contexts, the conception of work to-day must situate it in the contemporary context of democratic societies.

Our argument, that social interactions at work go beyond instrumentality, rests on two claims: first that workers to-day aspire to egalitarian, democratic interactions, and second that work entails cooperative behaviour.

The first claim consists in acknowledging that the egalitarian interaction regime specific to our democracies pervades all interpersonal exchanges, including interactions at work. In contemporary work environments, even though democracy stops at the firms' doors, hierarchical decisions do not go unquestioned. Democracy does not abolish the existence of bosses and employees, but it alters the rationale underlying human interactions and creates a tension between the norm of equal status in the wider polity and that of subject status in the workplace that must be acknowledged. Even when the interaction context is hierarchical, there is an inescapable aspiration to relational horizontality (Martucelli, 2002) and fair treatment. Workers expect to be treated and recognized as distinct and morally able individuals. Expecting interactions at work to be egalitarian, or at least respectful of one's integrity and dignity, means expecting behaviours to be driven by social norms, most of which related to fairness and justice principles, such as the norm of reciprocity. Treating others and being treated according to such norms imply going beyond instrumentality.

The second claim and decisive theoretical point is the acknowledgement of the co-operative character of work. Indeed, most contemporary work activity involves some form of co-operation which, unlike coordination, mobilizes moral and normative abilities (Lopes, 2011). Because she conceives workplaces as inhabited by indistinct and interchangeable individuals, Arendt explicitly rejects that work entails some form of co-operation:

\footnotetext{
"Division of labour is based on the fact that two men can put their labour power together and behave toward each other as though they were one. This one-ness is the exact opposite of co-operation, it indicates the unity of the species with regard to which every single member is the same and exchangeable” (Arendt, 1958, p. 123).
}

However, if well-defined tasks can be efficiently coordinated by technical or hierarchical mechanisms, most modern productive activities require a high level of interdependence between workers and entail 
high levels of task and role ambiguity. The workers' goals and effort levels cannot be defined independently and exogenously; instead, the workers must, together, develop a common understanding of the problem to be solved and of how this can be done. In collective endeavours, the definition of each member contribution is endogenous to the group. What ensues from this interdependency is that (a) the workers involved must be subjectively committed and (b) compliance with commitments and expectations about others' behaviour acquire crucial importance. Co-operating implies giving up on one's desire to cheat or exploit co-operative partners, which means going beyond instrumental or strategic interactions.

Neoclassical economists also resisted recognizing the existence and importance of co-operation in economic affairs, but they have been admitting it in the last decades. In mainstream accounts, though, the bedrock of co-operation is made of calculations of the relative costs/benefits of alternative actions - that is, people are assumed to co-operate for self-interested, instrumental reasons. But if co-operation no doubt entails a calculative facet, it also inevitably requires the relational and moral capacity of individuals. The conditions required to sustain co-operation in the formal mainstream models are simply not met in real-world contexts (Kotzebue and Wigger, 2010).

In a totally different strand of literature, the role of consent and co-operation at workplaces has been shown to be at least as important as that of coercion (Burawoy, 1979) ${ }^{3 .}$ Co-operating workers are, for the best and the worst, a vital ingredient for the functioning of productive organizations.

Acknowledging, contra Arendt, that workers do co-operate means recognizing that they relate with each other as distinct, unique and moral individuals. In fact, the very abilities required to sustain co-operation, that is, virtues and moral concerns, are those assigned exclusively to (political) action by Arendt and communicative action by Habermas. Conceiving work as permeated by egalitarian aspirations and co-operative behaviour means going beyond instrumentality and recognizing that work environments are arenas where individuation and distinctiveness, the processes assigned to the political sphere, also take place. The next section briefly presents Arendt's definition of the "political" and further develops the idea that work has a political dimension. Again, the argument is mostly grounded on how work is actually experienced by workers - a perspective seldom taken in social philosophy and economics.

\section{The political dimension of work}

Arendt explicitly states that labour is an "anti-political way of life” (Arendt, 1958, p. 212) because, as

\footnotetext{
3 Two different types of cooperation are here at stake. While the paragraphs above alluded to "horizontal" cooperation between workers involved in collective endeavours, Burawoy refers to the "manufactured" "vertical" cooperation between workers and the organization. Despite their substantial difference, both forms of cooperation are relevant for our argument.
} 
mentioned above, she assumes that labour does not take place between unique and distinct men. It is only through (political) action that men can distinguish themselves as distinct and unique beings, that is, only action makes man a political being. Acting means, for Arendt, initiating something in the world, something related to the way men live together and which transcends mere productive activity. Through action and speech, which are always linked, men show who they are and reveal their unique personal identities. When Arendt speaks of speech she is referring to the act of "communicating oneself" rather than communicating something or in order to obtain something. "The polis $[\ldots]$ is the organization of the people as it arises out of acting and speaking together” (Arendt, 1958, p. 198).

For Arendt, the organizing principle itself derives from the political realm; it is related to the man's capacity to act together ${ }^{4}$. Yet, once we recognize that there is an inescapable co-operative dimension in work, it logically follows that the organizing principle also permeates work environments. Indeed, as mentioned above, co-operating implies by definition that workers organize themselves, "act and speak together" and behave "virtuously" toward each other. The exercise of virtue is precisely the motive underlying action in Arendt's framework. Evidence has been collected by hundreds of institutional economists, sociologists and social psychologists (Cohen-Charash and Spector, 2001) on the prevalence of justice and other moral motives in behaviour at work - a trait largely explored by managers. It is not because the economic sphere is dominated by the profit rationale that all acts and behaviours in the economic sphere endorse the same instrumental rationality. Workers are not always the effort-avoiders and opportunistic individuals depicted in mainstream economic models.

In private business firms, work organization is decided by managers, not by workers, but all empirical studies reveal that workers do want to have a say on the way work is organized. In a detailed study of supermarket check-out clerks, Ferreras (2007) documents that even when work consists of the most repetitive and dull tasks, the workers are confronted with different normativity sources. While most managers try to impose a hierarchical type of interaction, the workers' aspiration is to institute an egalitarian dimension in their interactions with colleagues but also with managers. Workers particularly insist on the fact that managers' behaviours and decisions are often unjust, benefitting some workers at the expense of others. Contrary to the type of relations typical of instrumental action, where "ego establishes a relation with alter only when and if the one needs the other, and the counterpart is seen only as a means in order to achieve some goal that is external to the relation itself" (Bruni, 2005, p. 226), the supermarket clerks denounce the unfair way in which some colleague is treated and demand that the timetables, for instance, be decided collectively.

In democratic societies, the subjective dimension of work experience cannot be discarded, though caution must be taken for it not to obscure the objective circumstances of work. All empirical

\footnotetext{
${ }^{4}$ Arendt distinguishes the division of labour, which is a principle ruling labour and work, from the organizing principle, which she exclusively assigns to the public/political sphere.
} 
studies report that the workers are deeply subjectively - and hence intersubjectively - engaged at work, even when the engagement takes the negative form of deliberate withdrawal (Dejours, 2009). On the one hand, workers value and seek interpersonal interactions for their own sake, not for instrumental reasons (Lopes, 2011). On the other hand, these interpersonal interactions are expected to conform to the egalitarian interaction regime. The workers' claim to interact democratically with co-workers and supervisors, combined with the many co-operative facets of work, constitute definite instances of the political dimension of work. It suggests that action, in the arendtian sense, does or could take place also in workplaces, which would mean that work entails a public, as well as political, dimension.

\section{THE DEFINING FEATURES OF THE PUBLIC SPHERE AND THE EXTENT IN WHICH THEY APPLY TO THE WORK SPHERE}

Before we can answer the question to which we now turn - to what extent do workplaces entail a public dimension? - some defining features of what is a public sphere must be given. Previous sections broadly set the stage. For Arendt and Habermas, to the extent that they are dominated by instrumental and strategic action, workplaces are definitely excluded from the public sphere. Only action (for Arendt) and communicative action (for Habermas) belong to the public sphere. For both authors, notwithstanding their theoretical divergence on other aspects, the basic defining characteristic of the public sphere is the type of interaction herein established; the public sphere emerges whenever and wherever "men act together in concert". In other words, the extent to which a realm is public depends, according to Arendt and Habermas, on the way individuals interact and on the conditions in which interactions take place.

\section{The distinction between the public and the private in Arendt and Habermas}

For Arendt, public is almost synonymous with political (but the relation between the two is a perennial debate in political philosophy; see Frazer, 2009). Therefore, what has been said about work, action and the political also applies to work and the public. Arendt characterizes the public sphere by selfgovernment among distinct and equal individuals freed from the bonds of necessity; it stands in opposition to the private sphere - households and economic units, characterized by relations of domination and governed by necessity. The private is an intimate realm sheltered from external scrutiny, which deals with production and reproduction, while the public denotes a collective body, visible and open to all, engaged in deliberating about how one should live together. There is no 
particular location or institution associated to the public sphere; a place becomes public whenever common action coordinated through speech and persuasion happens (Benhabib, 1992).

The developments in the sections above were meant to argue that, to the extent that workers interact as distinct, individuated individuals able and wanting to participate in the organization of work, there is a political dimension of work. From this may be inferred that work also has a public dimension. However, Arendt defines the public by two basic constitutive features: distinctness and equality. If the distinctness quality of workers has been addressed in previous sections, the second requisite of the public sphere, that of equality, has yet to be examined.

Like Arendt, Habermas defines the public sphere by a particular type of interaction between individuals, named communicative action, which is marked by the search for mutual understanding and the non-manipulative use of language. For him, the public sphere is a theatre where citizens debate and deliberate about their common affairs under the constraints of an "ideal speech situation". These constraints include that

\footnotetext{
"each participant must have an equal chance to initiate and continue communication; each must have an equal chance to make assertions, recommendations and explanations; all must have equal chances to express their wishes, desires and feelings; and finally, speakers must be free to thematize those power relations that in ordinary contexts would constrain the wholly free articulation of opinions and positions. Together these conditions specify a norm of communication that can be named that of egalitarian reciprocity" (Benhabib, 1992, p. 89).
}

In the public sphere, then, competing particular interests are given equal consideration and participants deliberate as peers, in a search for consensus over the common interest. It is more than obvious that capitalist workplaces do not satisfy these criteria. Even when workers are allowed to express and defend their views, or when they are consulted on organizational matters, even in the most participative work environments, capitalist workplaces can never be regarded as collective deliberation arenas. Of course, consensus are sometimes reached about given issues but always through deliberative processes marked by subordination, since postulating the existence of a common good shared by firm owners and employees may well be a mystification.

However, one must not elude the fact that the workers' views and suggestions are based on organizational values and principles, that is, on normative claims that represent a - constrained thematization of power relations. To "carry on judging and attempting to validate one's judgments by persuading others" (Frazer, 2009, p. 216) is the very activity of the public: political sphere. In democratic societies, workers are always confronted with a conflict between their aspiration toward an egalitarian interaction regime and the actual hierarchical setting of business firms. Their judgments are not based on "private" values or opinions with a regard only to their individual, private situation; 
rather, they are formed by considering the whole collective of workers and grounded on public conceptions of justice (Ferreras, 2007). Even though workers are perfectly aware of their subordinate condition, they do not abdicate from being treated with justice. Clinical evidence on work-related psychological diseases testifies the pain and devastation that often result from unfair treatment at work (Dejours, 2009). Work is a normative experience; workers live and judge work events on the grounds of justice concerns.

Now, justice is, for most political philosophers, the good that is pursued in politics and debated in the public sphere, for it is through it that the common interest can be promoted ${ }^{5}$. In our societies, justice is precisely about the conflict between profit and right, efficiency and meaning, private claim and public policy; it is the concept "that enables us to make this transition from private to public, from 'I' to 'we'” (Pitkin, 1981, p. 347). Though workers lose most of the rights they have as citizens when they enter workplaces, they do not surrender their aspiration to the "egalitarian reciprocity”, the interaction regime progressively established in democratic societies. If the moral and normative abilities of individuals are the central institution of politics, and indeed of social order, then, workplaces have a public dimension, too.

However, the existence of an aspiration to equality does not mean its effectiveness. Arendt and Habermas were obviously right in saying that the realm of work will never be a sphere of freedom and equality. We may nonetheless hold from the argument developed so far that workplaces are potential by which we mean plausible in analytical terms even though not actually realized or realizable - public arenas.

It is because the criterion of equality is so ostensibly absent from the world of work that its public character is seldom discussed. But Arendt and Habermas' assumption of strict equality has been criticized for its illusory or elitist character. The issue deserves further examination.

\section{Equality as a criterion for a public sphere}

In the arendtian world, (political) action seems reserved to particularly endowed people. Indeed, action requires having an idea of the world and its future from a plurality of standpoints; being trusted by citizens - to the extent that it involves speaking in the name of others; having the ability to persuade others, and having the courage to engage in risky and uncertain ventures. Political action is far from easy then; as put by Frazer (2009, p. 221), “it is a human possibility, not the default setting”. In fact, it seems that most people are not up to it and indeed are excluded from it, which renders the equality criterion rather paradoxical.

\footnotetext{
${ }^{5}$ Arendt, in contrast to Aristotle, does not consider justice a key political value or principle because, since justice necessarily deals with economic and social circumstances, it is inevitably depoliticizing (Frazer, 2009).
} 
Habermas, in turn, considers that social, economic or status differences must be held in suspense when entering the public sphere for people to relate to one another as peers. However, it is illusory to think that the "bracketing" of inequalities can result in effective equality (Fraser, 1992). Social inequalities might contaminate and pervert deliberation, even when nobody is formally excluded from participation. Furthermore, assuming equality among participants may conceal their actually unequal cultural endowments and speech capacities. As rhetorical skills are unevenly distributed and speech is not power-neutral, “deliberation can function as a mask of domination” (Fraser, 1992, p. 119).

The very possibility of equality in existing societies is hence questioned, which raises doubts about the possibility of a public sphere itself (Fraser, 1992). We may however adopt a different perspective, decoupling equality from the requisite condition of public sphere and seeing it instead as the potentially equalizing outcome of "going public". This is paradoxically suggested by Arendt herself for whom equality is not an original condition; human beings are unequal in resources, capacities and status and need to be "equalized" (Arendt, 1958, p. 215). Now, for her, the most equalizing institution is open access to the public sphere. Equality hence appears as an outcome of action and participation in the public sphere rather than a prerequisite to it, which sheds a new (normative) light on the equality issue: equality may be seen as an ongoing process rather than an $a$ priori requirement. We argue below that, in the sphere of work, “equalization” may be promoted by the implementation of participatory workplaces.

The adoption of this perspective implies loosening (as feminists do) the public/private boundaries and qualify as public all arenas where social interactions give rise to experiences of (in)justice and democratic aspirations. Workplaces do satisfy such requisite. As sustained by Mahajan (2009), in contemporary democratic societies, the public and the private cannot be understood in opposition to each other.

\section{NORMATIVE IMPLICATIONS OF THE RECOGNITION OF THE PUBLIC CHARACTER OF WORK}

\section{Contesting and redefining the public-private boundaries}

Up to now, we concentrated on Habermas and Arendt's conceptions of the public sphere, which recognizedly are the most theoretically elaborated. We saw that, for both authors, work is definitely excluded from the public sphere because of (a) substantive and (b) procedural reasons: (a) work deals with the subsistence of workers and the economic interests of firms, which are instrumental and hence private matters; (b) decisions related to work are not subject to public deliberation, that is, taken by free, disinterested and equal individuals "acting in concert". 


\section{Claiming publicness for work}

But there are several other dimensions along which the public and the private may be distinguished. Public can mean i) public discussion and deliberation of shared interests, in the terms exposed in the previous sections; ii) state-owned rather than private property; iii) visible and open to everyone's scrutiny; iv) subject to public action or control; and v) of common concern because the consequences affect everyone. The aim of the first parts of the paper was to argue that work inescapably has a political, and hence public, dimension, to the extent that the type of values specific to political/public action also drives behaviour and interactions in workplaces. In the remaining of the paper we briefly reflect on the status of work at the light of the dimensions ii) to v).

We advanced above that workplaces are "potential” public arenas. Indeed, the definition of what is public is not only an analytical or theoretical matter but also a major political issue. As put by Benhabib (1992, p. 84), "all struggles against oppression in the world begin by" redefining what has previously been considered private, non-public, and non-political issues as matters of public concern, as issues of justice, as sites of power that need discursive legitimation”. Work began to become the focus of public attention, and a subject of public intervention, after the workers' struggles of the nineteenth century.

Of course, it is the private ownership of the means of production and the strict separation between the public and the private instituted by liberal thought that legitimize to a great extent the private character of work. Private property is at the centre of a rhetoric of privacy that has historically been used to restrict legitimate public contestation (Fraser, 1992, p. 131). Since the means of production are privately owned, workplaces are assumed to pertain to the private domain and this protects them from public interference and scrutiny. For liberal thought, the private sphere is not to be assessed from the standpoint of equality and justice and must be placed outside the scrutiny of the law and the state $e^{6}$.

But private ownership is not a legitimate reason for the non-recognition of the workers' rights as citizens. Once one accepts the principle, constitutive of democracies, of equal and fair treatment for all, no domain can be sheltered from the concerns of justice. Yet, as noted by Mahajan (2009, p. 139), while it is by now widely accepted that public concerns of justice and equality must apply to all forms of social interaction, there has been little effort to re-articulate the relationship between the private and the public. Redrawing the public-private boundaries and reflecting on how each sphere complements and interconnects with the other rather than considering them as separate and exclusive spheres is essential to democracy. In our societies, all social interactions are expected to abide by the principles of equality and justice enunciated in the public domain.

\footnotetext{
${ }^{6}$ Feminists have been the most active and effective in criticizing the strict separation between the public and the private (see, among others, Benhabib, 1992; Mahajan, 2009). Their argument, according to which the distinction between the private and the public furthered the subordination of women to the family and protected patriarchy, can plainly be extended to workers and firms.
} 
Applied to the sphere of work, this means that the workers have the right to reflexively question the issues affecting them and challenge and redefine what is or should be public and private. The European diversity concerning the workers' collective rights shows that private ownership does not constitute a legitimate obstacle to the workers' participation at different decision-making levels. Competition imperatives, ownership prerogatives and managerial concerns had been advanced to exclude issues such as work intensification, for instance, from public and political debate. Yet, the scope of the public debate must not be restricted by economic privacy. The quality of work life in particular should, like health and safety at work or working hours, cease to be a private business matter to become an issue of public concern.

Actually, firms face a permanent tension between a conflicting set of values. Because cooperation is required for the good functioning of productive organizations, firms more and more call for public values in their managerial discourses and practices to enhance the workers' involvement. For instance, some firms combine strict hierarchical structures with egalitarian interpersonal relations between workers and managers (Ferreras, 2007, p. 113-124). Others implement systems of employee voicing and build corporate cultures pervaded by values and principles specific of the public sphere. The latter stand, though, in patent contradiction with the values invoked to legitimate privacy and noninterference in management decisions. Normative elements imported from the public sphere - such as the right to have a voice - are hence brought into play, which perversely often prevent work from going public. Indeed, these discourses and practices are sometimes implemented to avoid unionization and promote the workers' identification with the organization rather than their emancipation. The result is organizational manipulation and the perpetuation of oppression in the name of overcoming it (Alvesson and Willmott, 1992).

What we have tried to emphasize is that the denial of the political and public dimension of work and workplaces may conceal the actual intertwining of the public and the private in productive organizations and undermine a sound analysis of its destructive and constructive potential.

\section{Recognizing the public dimension of work - Towards participatory workplaces}

Work began to progressively enter the public sphere at the end of the XIX century, with the first labour laws. A decisive step was the adoption in 1944, by all the signatories of the ILO, of the Declaration of Philadelphia (ILO, 1994), which states that "the representatives of workers and employers, enjoying equal status with those of governments, join with them in free discussion and democratic decision with a view to the promotion of the common welfare”. All constitutive features of the public sphere as conceived by Arendt and Habermas are present: it is recognized that work is a matter of common interest, subject to public deliberation among participants presumed to be free and equal. This Declaration was inspired by the industrial democracy strand of literature which advocates 
the establishment of institutional mechanisms for worker representation. Quite different industrial relations systems were set up throughout the twentieth century that allow workers to participate, through their representatives, in the discussion and deliberation on work-related matters at different levels (workplace, firm, industry, national).

Incidentally, one might note that, in the two last decades, the legitimated rights of workers are increasingly being seen as an impediment to economic and competitive performance. Indeed, the opinion that labour regulations constrain flexibility, inflate labour costs and promote segmented labour markets is now widely spread. Also, the idea that strikes interfere with the exercise of freedom of other citizens is becoming a matter of public debate. In other words, the publicness of work is seriously threatened. Union power is declining almost everywhere and work-related decisions are increasingly subjugated to economic concerns, that is, submitted to private interests rather than regarded as a common interest ${ }^{7}$.

But the primary focus of the present paper is the analysis of the public dimension of the activity of work itself, which is more directly associated to direct participation - that is, voice channels for influencing decision-making distinct from union-related instances - than representative participation. Direct voicing and participatory schemes have been denounced as an "integrationist" management agenda (Ramsay, 1983) on the ground that they may weaken unions, manipulate workers and break their solidarity. We nonetheless argue in favour of direct participation of workers alongside with representative participation whenever possible - because the normative counterpart of our analytical argument, that work has a public dimension, is the application to workplaces of the basic principle of the public sphere, namely the maximum possible participation of all those involved, not just the elected representatives.

This normative contention follows from our analytical argument but might be also grounded on the fact that the way in which work is organized deeply affects life in society. That is, the organization of work has a public impact, namely through its educative function. This idea was advanced long ago by John Stuart Mill (1848/1969), who claimed that participatory institutions provide a major opportunity to acquire political abilities and develop a public spirit. For Mill, there is an intimate relationship between the structure of institutions and the psychological qualities and attitudes of individuals interacting within them. When individuals are induced to participate in collective affairs, they widen their horizons by taking the public interest into account, which results in the development of their capacities for public action and ability to weigh interests not their own. Mill then suggested that participation in the "government" of workplaces would have the same educative impact on workers - which led him to see co-operatives as the ideal form of productive organization.

Building on Mill's insights, Pateman (1970) argues that direct participation at work is an

\footnotetext{
${ }^{7}$ Arendt and Habermas were right when they deplored that in contemporary societies economic concerns, that is, instrumental reason, came to occupy the whole public space.
} 
essential element of democracy. Participation in decision-making, when combined with forms of work organization that afford workers a large scope of discretion over their work ${ }^{8}$ contributes to develop the qualities needed for responsible public action - self-confidence, public-spiritedness, disposition to cooperate. In addition to these psychological benefits, participatory workplaces allow the gaining of practice in democratic and civic skills, which results in enhanced political participation. That is, the more control and influence individuals exercise over their work life, the more equipped and inclined they are to participate in community life. Empirical evidence has been collected that supports this thesis (Karasek and Theorell, 1990; Schur 2003; Godard 2007) - for instance, there is a clear correlation between work autonomy and civic participation levels (Lopes et al., 2012). Regardless, the study of the articulation between life at work and life in society remains a regrettably under-researched and neglected topic.

Mill and Pateman's claims meet the argument developed in the present paper. Indeed, if, as argued here, work has a political and public dimension, workplaces are logically arenas where workers acquire and "train" political skills and public spirit. Work plays an educative role in political and civic matters precisely because it has a political and public dimension.

Direct participation must not be confused with participation as a management technique, which can be associated with any form of work organization and whose aim is organizational efficiency. Practices used to persuade employees to accept decisions that have already been made by the management are but forms of pseudo participation (Pateman, 1970, p. 68-69). Effective participatory workplaces always involve a modification of the orthodox authority structure; decisionmaking ceases to be the prerogative of management, even if the latter retains the final power to decide. What Pateman really, and in our view rightly, wants to emphasize is the importance of participation at the workplace level, that of the content and methods of work, because low level participation is crucial to increase demand for higher level participation. Empirical studies show that there is a widespread desire among all categories of workers to influence their job and working conditions but that only a minority of workers wants to participate in higher decision-making levels. For Pateman, in the absence of the vital training ground of low level participation, only few workers (certainly the best educated) would take up the opportunity offered in a democratized system. That is, participation is cumulative in effect. Workplaces are essential elements of democracy to the extent that they may provide the opportunity to learn what is required for social evolution and the advent of more advanced democratic societies.

Unfortunately, observed trends go exactly against the desired evolution. A general decline of autonomy at work is reported in EU countries (Lopes et al., 2012) and workers, even when consulted,

\footnotetext{
8 That direct participation is combined with autonomy at work is a crucial point. Indeed, in some countries participation in decision-making is accompanied by declining discretion at work (Green, 2006). The ideal scenario would be the coexistence of direct and union channels of participation and high work autonomy.
} 
report that their voice is not actually taken into account. Besides, the introduction of individualized appraisal schemes is destroying former complicities between workers and installing instead untrustworthiness and disloyal competition, a situation which often results in deep psychological pain (Dejours, 2009). Fear and sanctions are often replacing trust and rewards as management and motivation devices. Such evolution provokes an erosion of the "elevated" traits of character needed for public action and may well be at the root of the present political desertion and erosion of civic solidarities. The fact is that, since work has become one of the main socializing agents, it is critical to the production of social cohesion: "society itself is produced and reproduced along the lines of relations found at work” (Cleghorn, 2007, p. 307). Now, with the exception of Nordic countries, the feeling of being disrespected, neglected and even humiliated is increasingly reported by workers in the EU.

The recent evolution of capitalism, marked by corporate governance, seems to have gone deeper in promoting particular interests over the general interest; in firms, management criteria lead to the interests of workers being disregarded in favour of those of shareholders, and in detriment of the common good. Contrary to what would be desirable for democracy, firms are isolating themselves from society in not attending the legitimate demand for participation at work.

Because it enables benefits to both the polity as a whole and the individuals involved, the promotion of participatory workplaces should be the object of public intervention. Appropriate public regulation is legitimized by the fact that the organization of work has a public impact and is rendered necessary by the imbalance of power between workers and employers, an imbalance that increased markedly in the last decades. Effective direct participation is very much influenced by work-oriented national policies and the features of the industrial relations system (Gonzalez Menendez, 2011). Based on the analysis of the relations between work and democracy, a "policy of work" concentrated on the organization of work should be promoted (Dejours, 2009). 


\section{Claiming publicness for work}

\section{CONCLUDING REMARKS}

The aim of the present paper was to argue, contra mainstream economists and also contra Hannah Arendt and Jurgen Habermas, that work goes beyond instrumentality and has a political and public dimension. Two main arguments ground our claim. Firstly, the conception of work today must situate it in contemporary societies and consequently acknowledge that the aspiration to an egalitarian interaction regime permeates all work experience. Secondly, work involves co-operative endeavours which call for the moral ability of individuals, that is, their ability and will to go beyond instrumentality and commit to a shared goal. Now, behaving according to normative concerns and interacting with others with a view to "act in concert" constitute precisely the major features of the public sphere. However, even though work, as experienced by workers, entails a public dimension, the domination and inequality that define capitalist workplaces rule them out of the public sphere stricto sensu.

We were hence led to contesting the boundaries of the public and the private and seeing the public character of work as a political as well as an analytical trait. We then developed the normative claim associated to our analytical arguments and argued in favour of the democratization of work in the form of more participatory workplaces. In fact, conceiving work as a depoliticized and private activity prevents seeing the various conflictualities it conveys both for workers and firms and undermines a sound analysis of its destructive and constructive potential.

The distinctive feature of our approach was the focus on the intersubjective dimension, a dimension downplayed by the individualist framework of mainstream economics. Taking interactions between individuals as the ultimate unit of analysis constitutes since long the methodological hallmark of institutional economics. In conceiving work as an activity relating individuals with nature rather than with each other, mainstream economists discharged it from the complexity of human relations, thus subtracting it from the political domain. In contrast, concentrating on the interpersonal level of analysis allowed us to unveil the intersubjective dimension of work and relate work with the public sphere, primarily defined by the fact that it puts "men together" (Arendt, 1958).

Our aim was to repoliticize the concept of work and hence to restore its critical function. Of course, Habermas and Arendt's purposes were more than laudable. Their theoretical constructions were aimed at denouncing the transformation of contemporary societies into consumer societies in which the public sphere is being taken over by economic concerns. But in reducing work to necessity and instrumentality, they contributed to condemn the work concept to a subaltern theoretical status, thus involuntarily reinforcing the derogatory mainstream economics approach to work. We attempted instead to re-dignify the concept of work, so central in the works of the nineteenth century classical economists, and to retrieve its emancipatory potential. However, the claims made here call for much 


\section{Claiming publicness for work}

further analytical investigation and their normative implications should be more elaborated.

In conceiving work as a mere instrumental activity, the risk is, to use Arendt's words against herself, that "the trouble with modern theories is not that they are wrong but that they could become true [... ending .... in the most sterile passivity history has ever known” (Arendt, 1958, p. 342). The recognition of the political and public character of work helps seeing that democracy is seriously undermined by the changes being experienced in the world of work and may hopefully prompt action able to reverse the trend. 


\section{REFERENCES}

ALVESSON, Mats and Willmott, Hugh (1992): Critical Management Studies, London, Sage

Publications.

ARDITI, Benjamin (2009): Disagreement without reconciliation: Democracy, equality and the public realm, Critical Review of International Social and Political Philosophy, 12(2):167-181.

ARENDT, Hannah (1958): The Human Condition, Chicago: University Chicago Press.

BENHABIB, Seyla (1992): "Models of public space: Hannah Arendt, the liberal tradition, and Jurgen Habermas”, in Calhoun, Greg (ed.): Habermas and the public sphere, Cambridge: The MIT Press.

BRUNI, Luigino (2005): "Hic sunt leones: interpersonal relations as unexplored territory in the tradition of economics", in Gui, Benedetto and Robert Sugden (ed.) Economics and Social Interactions, Cambridge, Cambridge University Press.

BURAWOY, Michael (1979), Manufacturing Consent : Changes in the Labor Process Under Monopoly Capitalism, University of Chicago Press.

CLEGHORN, Stephen (2007): Can workplace democracy transform capitalist society? Durkheim and Burawoy compared, Sociological Inquiry, 57(3): 304-315.

COHEN-CHARASH YOCHI, Spector Paul (2001): "The Role of Justice in Organizations: a MetaAnalysis”, Organizational Behavior and Human Decision Processes, vol. 86, nº 2:278-321.

Dejours, Christophe (2009): Travail Vivant - Travail et Émancipation, Paris: Payot.

FERRERAS, Isabelle (2007): Critique Politique duTtravail, Paris: Presses de Sciences Politiques.

FRASER, Nancy (1992): "Rethinking the public sphere” in Calhoun, Greg (ed.): Habermas and the public sphere, Cambridge: The MIT Press.

FRAZER, Elizabeth (2009): Hannah Arendt: The risks of the public realm, Critical Review of International Social and Political Philosophy, vol 2(2):203-223. 
GODARD, J. (2007). Is good work good for democracy? Work, change at work and political participation in Canada and England. British Journal of Industrial Relations, 45(4): 760-790.

GONZALEZ MENENDEZ, Maria (2011): The determinants of workplace direct participation, Work, Employment and Society, 25(3): 397-416.

GREEN, Francis (2006): Demanding Work, Princeton and Oxford, Princeton University Press.

HABERMAS, Jurgen (1989, first ed. 1962): The Structural Transformation of the Public Sphere: An Inquiry into a Category of Bourgeois Society, Cambridge Massachusetts: The MIT Press.

HONNETH, Axel (1982): Work and instrumental action, Journal of Critical Theory and Modernity, 26:31-54.

ILO (1974): Constitution of the International Labor Organization, http://www.ilo.org/ilolex/english/iloconst.htm, accessed 22 February 2012.

KARASEK, Robert and Theorel Tores (1990): Healthy work: stress, productivity and the reconstruction of working, New York: Basic Books.

KOTZEBUE, Alexander and Berthold Wigger (2010): Private contributions to collective concerns: modeling donor behavior, Cambridge Journal of Economics, 34: 367-387.

LOPES, Helena (2011): Why do people work? Individual wants versus common goods, Journal of Economic Issues, 45 (1): 57-74.

LOPES, Helena, Lagoa, S., Calapez, T., (2011), “Declining autonomy at work in the EU and its effect on civic behaviour”, Working Paper DINÂMIA’CET nº.2011/11, Lisboa.

MAHAJAN, Gurpreet (2009): Reconsidering the private-public distinction, Critical Review of International Social and Political Philosophy, 12(2):133-143.

MILL, John Stuart (1969/1848): The principles of Political Economy. New York: Augustus Kelley Publishers. 
PATEMAN, Carole (1970): Participation and Democratic Theory, Cambridge: Cambridge University Press.

RAMSAY, Harvie (1983): Evolution or cycle?, in Crouch C. And F. Heller (ed.): Organizational Democracy and Political processes, Hoboken: John Wiley, PP. 203-225.

SCHUR, Lisa (2003). Employment and the creation of an active citizenry. British Journal of Industrial Relations, 41(4): 751-771.

SPENCER, David (2009). The Political Economy of Work, London and New York: Routlegde. 